\title{
Wheat Bran Dietary Fiber: Promising Source of Prebiotics with Antioxidant Potential
}

\author{
Aynur Gunenc ${ }^{1}$, Christina Alswiti ${ }^{1} \&$ Farah Hosseinian ${ }^{1,2}$ \\ ${ }^{1}$ Food Science and Nutrition Division of Chemistry Department, Ottawa, Ontario, Canada \\ ${ }^{2}$ Institute of Biochemistry, Carleton University, Ottawa, Ontario, Canada \\ Correspondence: Farah Hosseinian, Food Science and Nutrition Division of Chemistry Department, and Institute \\ of Biochemistry, Carleton University, Ottawa, Ontario, Canada. Tel: 1-613-520-2600, ext.2048. E-mail: \\ farah_hosseinian@carleton.ca
}

Received: September 21, 2016

Accepted: December 23, 2016

Online Published: January 28, 2017

doi:10.5539/jfr.v6n2p1

URL: http://dx.doi.org/10.5539/jfr.v6n2p1

\begin{abstract}
The potential of wheat bran (WB) addition as a prebiotic source were demonstrated using yogurt with probiotics (Lactobacillus acidophilus and Bifidobacterium lactis). Yogurts (with 4\% WB) were significantly $(P<0.05)$ different in total bacterial counts $(9.1 \log \mathrm{CFU} / \mathrm{mL})$, and total titratable acidity \% (TTA, $1.4 \%$ ) compared to controls during 28 days cold storage $\left(4^{\circ} \mathrm{C}\right)$. Additionally, WB-total dietary fiber contents and their bound phenolic profiles were investigated as well as the antioxidant activity of WB-water extractable polysaccharides (WEP) was studied. HPLC analysis of alkaline hydrolyzed DF fractions showed that insoluble DF had higher phenolic acids $(84.2 \%)$ content than soluble DF (15.8\%). Also, crude-WEP showed stronger antioxidant activity compared to purified-WEP with an ORAC of 71.88 and $52.48 \mu \mathrm{mol} \mathrm{TE} / \mathrm{g}$, respectively. Here we demonstrate WB has potentials as a source of prebiotics, which may have the potentials for functional foods and nutraceutical applications.
\end{abstract}

Keywords: Bound phenolics, dietary fiber, DPPH, ORAC, prebiotics, wheat bran

\section{Introduction}

Increased whole grain consumption is linked to a decreased risk of chronic diseases (Fardet, 2010) such as obesity (Jonnalagadda et al., 2011), type II diabetes (Murtaugh et al., 2003), cardiovascular disease (Mellen, Walsh, \& Herrington, 2008) and cancer (Schatzkin et al., 2008). Wheat (Triticum aestivum), is second to rice as the main staple food crop. Most bioactive components (e.g. phenolic acids, alkylresorcinols) and dietary fiber $(45 \%)$ are present in wheat bran (WB) fractions that represent 14-16\% of the grain by weight (Fardet, 2010).

Cereal grain oligosaccharides act as prebiotics (a non-digestible food ingredient/soluble dietary fiber) and increase beneficial bacteria (probiotics) amount in the large bowel, thus improving gut health (Topping, 2007). They are a nutritional substrate for the probiotics in the colon and have the potential to improve host health (Chakraborti, 2011). Meanwhile phenolic compounds (e.g. ferulic and gallic acids) are related to prevention of diseases through some potential mechanisms such as free radical quenching, transition-metal chelation, and stimulation of the antioxidant enzyme system (Aaby, Skrede, \& Wrolstad, 2005). Probiotics and prebiotics are commonly used in fermented dairy products (Kanmani et al., 2013) and supplementary research is desired to discover bio-products and their potential use in functional foods or nutraceuticals. Therefore, it was aimed to; 1 ) investigate the prebiotic effects of WB addition on microbial counts as colony forming units (CFU), and TTA in yogurts with and without probiotic bacteria, 2) measure the antioxidant activity of crude- and purified-WEP by oxygen radical absorbance capacity (ORAC), and 2, 2-diphenyl-1-picryhydrazyl (DPPH) assays along with total phenolic content (TPC), and 3) determine WB-total DF content (SDF, IDF) and analyze the phenolic acids and flavonoid composition of each fiber fraction as well as WB.

\section{Materials and Methods}

\subsection{Materials}

Analytical grade solvents including acetone, ethanol, methanol, ethyl ether, HCL, and ethyl acetate were purchased from Caledon Laboratories LTC (Georgetown, ON, Canada). Over $98 \%$ pure of fluorescein, mono-and dibasic potassium phosphate, Trolox (6-hydroxy-2,5,7,8-tetramethylchroman-2-carboxylic acid), 2, 2'-azobis 
(2-methylpropionamidine) dihydrochloride (AAPH), Folin- Ciocalteu (FC) reagent, $\alpha$-tocopherol, and 2, 2-diphenyl-1-picryhydrazyl radical (DPPH), $\mathrm{NaOH}$, sodium carbonate phenolphthalein were obtained from Sigma (Oakville, ON, Canada). Protease from Bacillus licheniform (saline solution $\geq 2.4 \mathrm{U} / \mathrm{g}$ protein, EC 232-560-9) and $\alpha$-amylase from Bacillus licheniformis (Type XII-A, saline solution $\geq 500 \mathrm{U} / \mathrm{mg}$ protein, EC 232-752-2) were purchased from Sigma-Aldrich (St. Louis, Missouri, USA). The starter cultures, (Lactobacillus delbrueckii ssp. bulgaricus (B-548; USDA) and Streptococcus salivarius ssp. thermophilus (14485; ATCC)), probiotics (Lactobacillus acidophilus (B-4495, USDA) and Bifidobacterium lactis (41405, USDA)), Man Rogosa Sharpe (MRS) broth liquid and MRS agar media were purchased from Oxoid Ltd. (Basingstoke, United Kingdom).

Phenolic acids (gallic, protocatechuic, p-OH-benzoic, chlorogenic, caffeic, vanillic, syringic, p-coumaric, sinapic, ferulic, o-coumaric) and flavanoid standards (pyrogallol, catechin, epicatechin, rutin, quercetin-3-beta-glucoside, epicatechin gallate, myricetin, quercetin, apigenin and kaempherol) were purchased from Sigma-Aldrich (St. Louis, Missouri, USA).

\subsection{Prebiotic Activity}

\subsubsection{Sample Preparation}

Wheat bran (WB) was kindly provided by Kraft Canada, freeze dried and kept in sealed plastic bags $\left(-20^{\circ} \mathrm{C}\right)$ until further use. Before use, it was ground to $0.5 \mathrm{~mm}$ particle size at Agriculture-Canada (Ottawa, ON, Canada) Laboratories using a cyclone sample mill (UDY Corporation, CO, USA).

\subsubsection{Milk Preparation}

Pasteurized whole milk (3.25\%), purchased from a local market, was heated at $85^{\circ} \mathrm{C}$ for 15 minutes, cooled down to $42^{\circ} \mathrm{C}$ in a water bath and transferred into $50 \mathrm{~mL}$-sterile test tubes. The starter cultures, probiotics, and $4 \%$ WB were added and incubated at $42^{\circ} \mathrm{C}$ until the yogurt reached $\sim \mathrm{pH} 5.0$ (Santo et al., 2010). All treatments were done in triplicates.

\subsubsection{Microbial Cultures}

The starter cultures (Lactobacillus delbrueckii ssp. bulgaricus and Streptococcus salivarius ssp. thermophilus), probiotic 1 (Lactobacillus acidophilus) and probiotic 2 (Bifidobacterium lactis) were employed to make all yogurt trials as shown in Table 1 . For each strain, sterile aliquots of MRS broth $(10 \mathrm{~mL})$ were used to grow microorganisms (incubated at $37^{\circ} \mathrm{C}$ for $24 \mathrm{~h}$ ). For stock culture, activated tubes were used after three successive rinses with sterilized distilled water. Then the cultures were diluted with sterilized milk $\left(121^{\circ} \mathrm{C}\right.$ for $15 \mathrm{~min}$ in an autoclave) to obtain a concentration of $6.5 \log$ bacteria cells $/ \mathrm{mL}$ and then added to the tubes depending on the trials (Table 1) and the initial $\mathrm{pH}$ recorded. There were a total of eight yogurt trials including four with WB (4\%) and four as controls without WB. Yogurts with WB were compared against corresponding controls. All tubes were incubated at $42^{\circ} \mathrm{C}$ for fermentation and $\mathrm{pH}$ was measured after $4 \mathrm{~h}$ and $1 \mathrm{~h}$ thereafter. When the $\mathrm{pH}$ reached approximately 5 , all tubes transferred were stored at $4{ }^{\circ} \mathrm{C}$ (Santo, et al., 2010).

Table 1. The experimental design used to evaluate the effect of WB addition on microbial counts in different yogurt trials

\begin{tabular}{lc}
\hline Yogurt trials & Sample coding \\
\hline $\mathrm{Y}$ & $\mathrm{Y}$ \\
$\mathrm{Y}+$ Pro 1 & $\mathrm{Y}+1$ \\
$\mathrm{Y}+$ Pro 2 & $\mathrm{Y}+2$ \\
$\mathrm{Y}+$ Pro 1 \& Pro 2 & $\mathrm{Y}+1+2$ \\
$\mathrm{Y}+\mathrm{WB}$ & $\mathrm{YB}$ \\
$\mathrm{Y}+\mathrm{WB}+$ Pro 1 & $\mathrm{YB}+1$ \\
$\mathrm{Y}+\mathrm{WB}+$ Pro 2 & $\mathrm{YB}+2$ \\
$\mathrm{Y}+\mathrm{WB}+$ Pro 1 \& Pro 2 & $\mathrm{YB}+1+2$ \\
\hline
\end{tabular}

$\mathrm{Y}=$ standard yogurt containing only starter cultures of Lactobacillus bulgaricus and Streptococcus thermophiles. Pro $1=$ probiotic Lactobacillus acidophilus, Pro 2 = probiotic Bifidobacterium lactis, WB = wheat bran (4\%). Equal volumes of each bacterium (6.5 log bacteria cells $/ \mathrm{mL}$ ) were added to the tubes depending on the treatments 


\subsubsection{Microbial Count}

On days 1, 7, 14, 21 and 28, total microbial counts were carried in triplicate for each batch at different dilutions; four serial dilutions of 1 to 10 . An aliquot $(5 \mu \mathrm{L})$ from each dilution was plated on MRS agar dishes using a spread plate method and incubated at $37^{\circ} \mathrm{C}$ for $24 \mathrm{~h}$ (Santo, et al., 2010).

\subsubsection{Total Titratable Acidity (TTA) Measurements}

Percent TTA for all yogurts were determined on the same days $(1,7,14,21$ and 28 in triplicate) by titrating each yogurt sample with $0.1 \mathrm{~N} \mathrm{NaOH}$ using $0.1 \%(\mathrm{w} / \mathrm{v})$ phenolphthalein as an indicator. Additionally, $\mathrm{pH}$ of all yogurts were recorded on each day (Denver Instrument UB-5 pH meter) (Behrad, Yusof, Goh, \& Baba, 2009).

\subsection{Water Extractable Polysaccharides (WEB) -Antioxidant Activity}

\subsubsection{WEP-Extraction}

Crude-WEP: WB and distilled water were mixed $(1: 100, \mathrm{w} / \mathrm{v})$, stirred $\left(70^{\circ} \mathrm{C}\right.$ for $\left.4 \mathrm{~h}\right)$, cooled, centrifuged at 6000 $\mathrm{x} \mathrm{g}$ for $20 \mathrm{~min}$ (Thermo Sorval, Legend XT Series, Fisher Scientific, Nepean, ON, Canada) and the supernatant was retained for further analysis.

Purified-WEP: Starch and proteins/peptides were removed by using $\alpha$-amylase and protease to the supernatant solution $(20 \mu \mathrm{L} / 100 \mathrm{~mL})$ and agitated at $37^{\circ} \mathrm{C}$ for $24 \mathrm{~h}$. Then the supernatant was cooled and centrifuged $(6000 \mathrm{x}$ $\mathrm{g}$ for $20 \mathrm{~min}$ ). The supernatant was dialyzed against double distilled water for $48 \mathrm{~h}$ and replaced with fresh distilled water every $6 \mathrm{~h}$ to separate polysaccharides and other materials with a molecular weight cut-off of 3500 $\mathrm{Da}$ (Spectra/Por, CA, USA). The extract was kept at $-20^{\circ} \mathrm{C}$ until further analysis (Escarnot et al., 2011).

\subsubsection{Total Phenolic Content (TPC)}

Crude- and purified-WEP total phenolic contents were measured by the Folin-Ciocalteu (FC) method (Gao, Wang, Oomah, \& Mazza, 2002). Each sample extract of $200 \mu \mathrm{L}$ was mixed with FC reagent $(1.9 \mathrm{~mL}$ of 10 -fold diluted FC), and then $1.9 \mathrm{~mL}$ of sodium carbonate solution $(60 \mathrm{~g} / \mathrm{L})$ was added to the mixture. All tubes were stored in the dark at room temperature for $2 \mathrm{~h}$, and the absorbance values were recorded at $725 \mathrm{~nm}$ (UV-Vis. Spectrophotometer, Cary 50 Bio, Varian Inc., Australia) against a blank of distilled water. Ferulic acid (FA) was employed as standard, and TPC values were calculated as FA equivalents per gram of samples (Gunenc, HadiNezhad, et al., 2013).

\subsubsection{DPPH Assay}

For DPPH radical scavenging activity of crude- and purified-WEP, Brand-Williams et al. (1995) study was followed. Each sample extract $(200 \mu \mathrm{L})$ was reacted with DPPH solution $(3.8 \mathrm{~mL})$ for $1 \mathrm{~h}$, and then absorbance (A) values of the mixture at $515 \mathrm{~nm}$ were read against a blank of pure $95 \%$ ethanol. The antioxidant activity was calculated as \% discoloration (Gunenc, Tavakoli, et al., 2013; Li et al., 2009).

\subsubsection{Oxygen Radical Absorbance Capacity (ORAC) Assay}

ORAC values of crude- and purified-WEP were determined by a fluorometric micro plate reader (FLx $800^{\mathrm{TM}}$ Multi-Detection Micro plate Reader with Gen $5^{\text {TM }}$ software, BioTek Instruments, Ottawa, Canada) described by Gunenc et al., (2013). All analyses were carried out at $37^{\circ} \mathrm{C}$ with a 20 min incubation and 60 min run-time. A micro plate was prepared containing $20 \mu \mathrm{L}$ of Trolox standards, sample dilutions, as well as $120 \mu \mathrm{L}$ of fluorescein (FL) solution. After the incubation of the plate, $60 \mu \mathrm{L}$ of $153 \mathrm{mM}$ AAPH was added quickly to each well for a final volume of $200 \mu \mathrm{L}$. FL micro plate reader was used to read the absorbance during run-time (at an excitation wavelength of $485 \mathrm{~nm}$ and an emission wavelength of $525 \mathrm{~nm}$ ). ORAC values were calculated by the differences of net areas under the FL decay curves between the blank and sample and were expressed as micromole Trolox Equivalents per gram of sample ( $\mu \mathrm{mol} \mathrm{TE} / \mathrm{g}$ ) (Gunenc et al., 2015; Ou et al., 2002).

\subsection{Total Dietary Fiber (TDF) and Its Phenolics}

\subsubsection{Extraction of TDF}

WB-Total dietary fiber as the sum of soluble dietary fiber (SDF) and insoluble dietary fiber (IDF) was calculated by following the AOAC Official Method (991.43). To remove starch and protein, WB (5 g) was exposed to enzymatic digestions; firstly, heat stable $\alpha$-amylase $(250 \mu \mathrm{L}$, boiling water bath for $30 \mathrm{~min})$, then alcalase protease $\left(50 \mathrm{mg} / \mathrm{mL}, 500 \mu \mathrm{L}, \mathrm{pH} 7.5,60^{\circ} \mathrm{C}\right.$ for $\left.30 \mathrm{~min}\right)$ and lastly, amyloglucosidase $\left(1500 \mu \mathrm{L}, \mathrm{pH} 4.5,60^{\circ} \mathrm{C}\right.$ for $30 \mathrm{~min})$. After centrifugation $(10,000 \mathrm{rpm})$, the residue was washed sequentially with hot water, ethanol (95\%), and acetone (95\%); filtered and recorded as IDF.

The combined supernatants from the washings was precipitated in ethanol $\left(80 \%\right.$, preheated to $60^{\circ} \mathrm{C}, 4$ volumes) overnight and recorded as SDF. The two fractions (IDF and SDF) were placed in a fume hood and dried at 
$35-40^{\circ} \mathrm{C}$ overnight to remove organic solvent (Guo \& Beta, 2013).

\subsubsection{Phenolic Compound Extractions from WB, SDF and IDF}

WB, SDF and IDF were alkaline hydrolyzed to release their bound phenolics and followed by liquid-liquid partitioning steps to extract those released phenolic compounds (Gunenc, et al., 2015; Guo \& Beta, 2013). More specifically, each sample (WB, SDF, and IDF) were mixed with $2 \mathrm{M} \mathrm{NaOH}$ and agitated at room temperature for 4 $\mathrm{h}$. Then, they were acidified (6M HCI) to $\mathrm{pH} 1.5-2$ and liquid-liquid partitioning steps were followed. The dried alkaline extracts were re-dissolved in MeOH and filtered (0.45 $\mu \mathrm{m}$ PTFE) before HPLC analysis (Kim, Tsao, Yang, \& Cui, 2006).

\subsubsection{HPLC Analysis of Phenolic Compounds from WB, SDF and IDF}

The extracts from section 2.4.2 were analyzed via a reverse phase (RP)-HPLC on the Alliance $®$ HPLC system e2695, Separation Module with the 2998 PDA (Waters, Mildford, Massachusetts, USA) with Empower 3 software. All phenolic acid and flavonoids standards as well as the extracts were prepared in methanol. To separate phenolic acids and flavonoids in a single run with a Synergy-Max-RP column, at $35^{\circ} \mathrm{C}$, solvent-A $(0.01 \%$ formic acid:Milli-Q water) and solvent-B (100\% acetonitrile) at a flow rate of $1.0 \mathrm{~mL} / \mathrm{min}$ and a linear gradient program from $90 \%$ to $50 \%$ solvent A in 35 min was developed. Phenolic acids $(280 \mathrm{~nm})$ and flavonoids $(320 \mathrm{~nm})$ were identified and quantified using 11 phenolic acids and 10 flavonoid standards (Gunenc, et al., 2015).

\subsection{Statistical Analysis}

Statistical analysis was performed using Analysis of variance (ANOVA) with Statistical Analysis System (9.2, SAS Institute Inc., Cary, NC). All experiments were accompanied in triplicates. Duncan's Multiple Range test was used when significant $(P<0.05)$ mean comparison was achieved.

\section{Results and Discussion}

\subsection{Prebiotic Activity}

\subsubsection{Microbial Count $(\log \mathrm{CFU} / \mathrm{mL})$}

Total microbial counts on days 1, 7, 14, 21 and 28 of fermentations in all yogurt trials were shown in Figure 1. By day 1 , microbial counts increased to a range of 8.19-8.31 $\log \mathrm{CFU} / \mathrm{mL}$ in control yogurts, and 8.41-8.65 $\log$ $\mathrm{CFU} / \mathrm{mL}$ in yogurts with WB from an initial bacteria count of 6.5 .

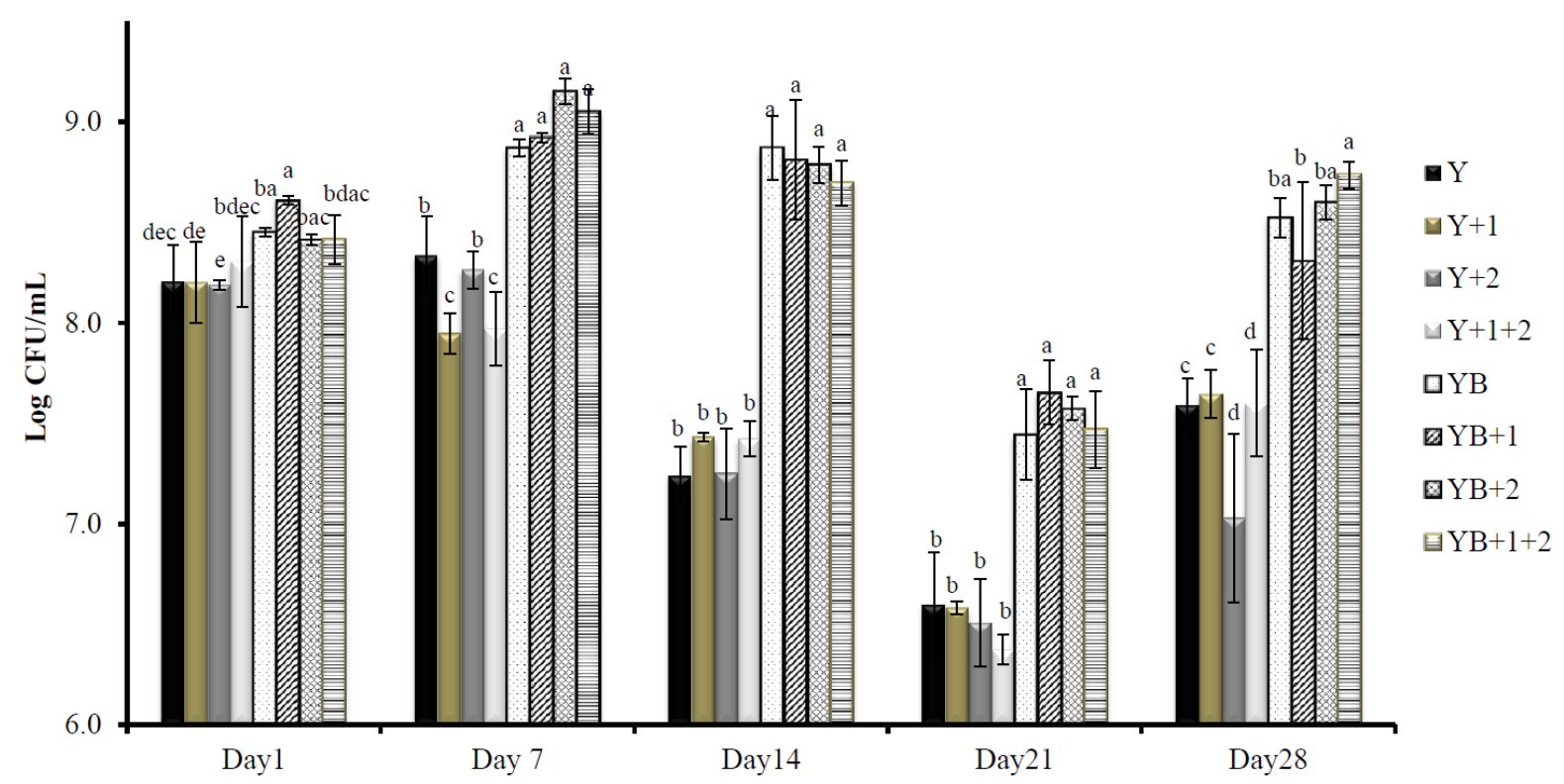

Figure 1. Total microbial count $(\log \mathrm{CFU} / \mathrm{mL})$ in control yogurts $(\mathrm{Y}, \mathrm{Y}+1, \mathrm{Y}+2, \mathrm{Y}+1+2)$ and yogurts with $4 \%$ wheat bran $(\mathrm{YB}, \mathrm{YB}+1, \mathrm{YB}+2, \mathrm{YB}+1+2)$. Different letters in columns on the same day are significantly different $(P<0.05)$ 
By day 7, the bacterial growth increased significantly $(P<0.05)$ in yogurts with WB $(8.87$ and $9.15 \log \mathrm{CFU} / \mathrm{mL})$ compared to their corresponding controls (7.94 to $8.34 \log \mathrm{CFU} / \mathrm{mL}$ ). By days 14 and 21, the CFU values in yogurt samples with and without WB continued to be significantly different.

By day 28, yogurt samples lacking WB had significantly $(P<0.05)$ lower total bacteria counts of 7.03-7.65 log $\mathrm{CFU} / \mathrm{mL}$ compared to $8.31-8.74 \log \mathrm{CFU} / \mathrm{mL}$ of yogurt samples with WB. It has been suggested that the amount of viable bacteria remaining in yogurt after four weeks of cold storage should be in the range of 6 to $8 \log$ $\mathrm{CFU} / \mathrm{mL}$ (Vasiljevic \& Shah, 2008). The controls remained within the range, but the yogurts containing WB had higher bacteria counts in the range of 8.31 and $8.74 \log \mathrm{CFU} / \mathrm{mL}$.

Overall, the yogurts with WB verified significantly higher bacteria counts $(P<0.05)$ during the four weeks of cold storage in comparison to control samples. It can be interpreted that in the presence of WB, there was an increase in microbial viability in sample trials consisting of probiotics. The randomized human study of François et al. (2012) showed that addition of 3g/day WB increased bifidobacteria (1.3 fold) and significantly increased faecal propionic acid levels (Francois et al., 2012). It may be a synergistic, additive or antagonistic effect of WB on probiotics compared to its corresponding controls. These results showed that WB might have a selective effect on increasing probiotics and starters during cold storage from day 1 to day 14, and to a lesser extent on day 21. A decreasing trend in CFU numbers may be a result of nutrient depletion over time or their metabolites (Sengun, Nielsen, Karapinar, \& Jakobsen, 2009). For all microbes, certain nutrients such as iron and manganese are necessary to promote viability and growth. At the same time, probiotic bacteria have the ability to bind these elements and reduce accessibility by pathogenic bacteria (Bomba, Nemcová, Mudronová, \& Guba, 2002). WB consists of manganese, and iron, with levels of 4-14 and 2.5-19 g/100g (Fardet, 2010).

Additionally, the Food and Drug Administration (FDA) has issued a letter of no objection for the WB extract Brana Vita, giving manufacturers a new prebiotic for a range of food and beverage products (Daniells, 2010). So, yogurts with WB and probiotics might supply micronutrients and oligosaccharides, selectively stimulating these particular bacterial strains (Costa, Queiroz-Monici, Machado-Reis, \& Oliveira, 2006).

\subsubsection{TTA \%}

During four weeks storage, TTA of all yogurt trials (Figure 2) with WB additions (YB, YB +1, YB +2, YB +1 +2) showed increasing TTA \%, indicating that lactic acid production was increased as a result of the growing number of bacteria. The control yogurts had significantly lower TTA\% than corresponding yogurts with WB. On day 28 , the yogurt treatment with both probiotics $(\mathrm{YB}+1+2)$ had the highest value from their corresponding control yogurt $(\mathrm{Y}+1+2)$. It might be due to secondary metabolites production (lactate, propionate, or ethanol) and their positive influence on cell viability (Rattanachaikunsopon \& Phumkhachorn, 2010). Moreover, volatile aroma compounds like carbonyl compounds might increase cell sustainability without impacting pH levels (Beshkova et al., 2003). The significant drop in $\mathrm{pH}$ on day 28 did not seem to intrude cell viability. Also parallel findings has been reported for improved probiotic viability in yogurt samples with low pH levels (4.1) in the presence of a prebiotic source (Agil \& Hosseinian, 2012; Santo, et al., 2010). 


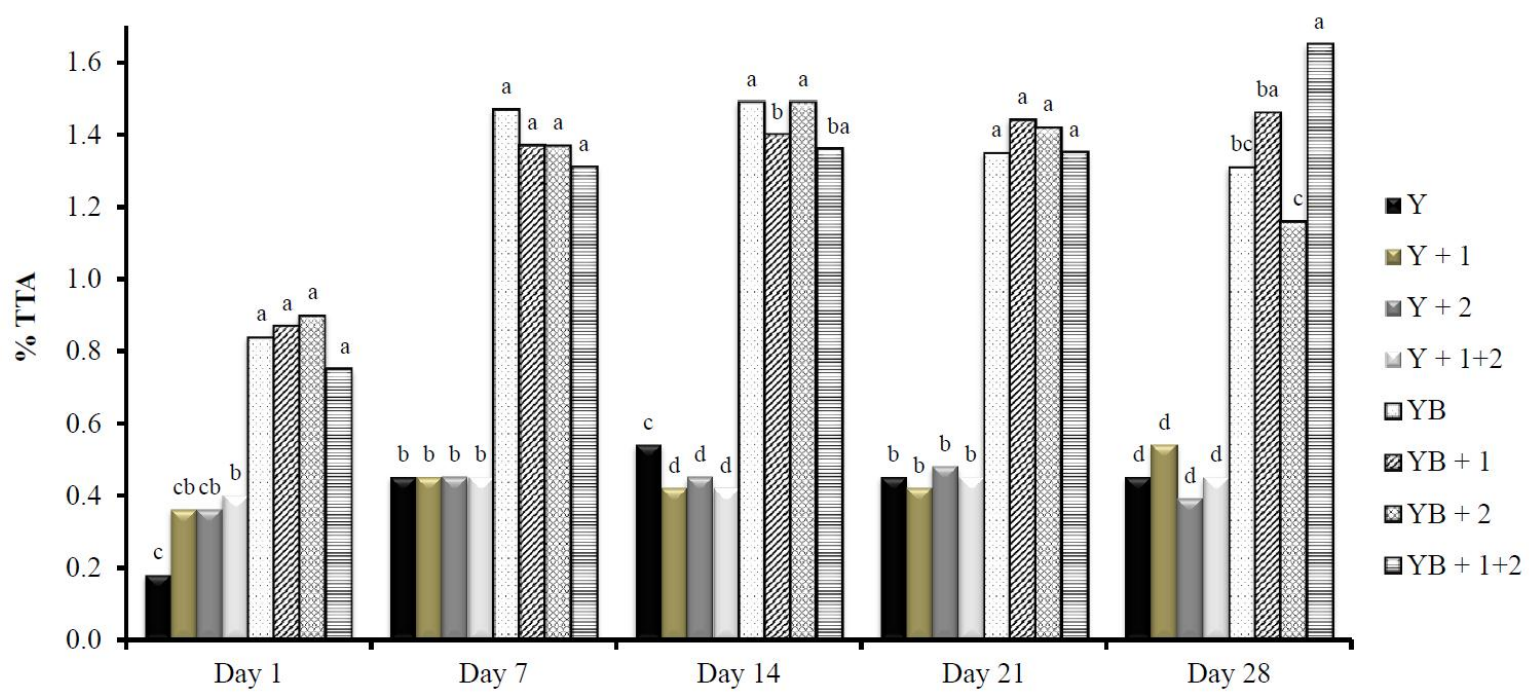

Figure 2. Percent total titratable acidity (\%TTA) in control yogurt $(\mathrm{Y}, \mathrm{Y}+1, \mathrm{Y}+2, \mathrm{Y}+1+2)$ and yogurt with $4 \%$ wheat bran $(\mathrm{YB}, \mathrm{YB}+1, \mathrm{YB}+2, \mathrm{YB}+1+2)$. Different letters in columns on the same days are significantly different $(P<0.05)$. TTA \% values in and. Number 1 and 2 represent probiotic1 and 2 . These results, parallel to our findings, suggest that the addition of WB to yogurts caused bacteria to produce more lactic acid, confirming findings obtained from the $\mathrm{pH}$ monitoring

\subsection{Antioxidant activity of WEPs}

\subsubsection{ORAC Assay}

The ORAC value (Table 2) of crude-WEP $(71.88 \pm 4.01 \mu \mathrm{mol}$ TE/g) was higher than purified-WEP $(52.48 \pm$ $2.05 \mu \mathrm{mol} \mathrm{TE} / \mathrm{g}$ ). Moore et al. (2006) reported ORAC values of 45 to $78 \mu \mathrm{mol} \mathrm{TE} / \mathrm{g}$ for 20 wheat bran samples (Moore, Liu, Zhou, \& Yu, 2006). Also in another study, ORAC values of six wheat ranged from 19.5 to 37.4 $\mu$ mole TE/g (Okarter, Liu, Sorrells, \& Liu, 2010). Our ORAC findings are higher than above mentioned studies. This might be due to different wheat varieties, particle size, and some differences in the experimental procedures. Also, the antioxidant activity could be attributed to the presence of bound phenolic acids in the crude extract (e.g. ferulic and p-coumaric acids) (Hosseinian \& Mazza, 2009). Moreover, presence of sugars with acyl groups and/or glycan-polymerization has been reported to have effects on the antioxidant activity of polysaccharides (Rao \& Muralikrishna, 2006).

\subsubsection{DPPH Assay}

The \%DPPH of crude- and purified-WEP were $9.65 \pm 0.17$ and $4.16 \pm 0.18$, respectively (Table 2). Similar to the study of Hromádková et al (2013), crude-WEP showed high antioxidant activity in both DPPH and ORAC tests (Hromádková et al., 2013). Phenolic components such as phenolic acids have been described to have a significant role in the overall radical scavenging capacity of xylans and xylooligosaccharides from the WB (Veenashri \& Muralikrishna, 2011).

Table 2. ORAC, DPPH and TPC values of WEP

\begin{tabular}{lcc}
\hline Antioxidant assays & Purified WEP & Crude WEP \\
\hline ORAC $(\mu$ mole TE/g) & $52.48 \pm 2.05^{\mathrm{b}}$ & $71.88 \pm 4.01^{\mathrm{a}}$ \\
$\%$ DPPH & $4.16 \pm 0.18^{\mathrm{b}}$ & $9.65 \pm 0.17^{\mathrm{a}}$ \\
TPC $(\mathrm{mg} \mathrm{FAE} / \mathrm{g})$ & $2.96 \pm 0.10^{\mathrm{b}}$ & $6.18 \pm 0.84^{\mathrm{a}}$ \\
\hline
\end{tabular}

ORAC $=$ Oxygen radical absorbance capacity as $\mu$ mole Trolox Equivalent (TE)/g of sample. DPPH $(\%)=2$, 2-Dipheny-1-picryhydrazyl radical (DPPH) radical scavenging activity assay TPC $=$ Total phenolic count was calculated as mg ferulic acid equivalent (FAE)/g of sample WEP $=$ Water extractable polysaccharides and values are means of triplicates \pm standard deviation $(\mathrm{SD})$ Different letters in rows are significantly different $(P<0.05)$ in Duncan's multiple range tests 


\subsubsection{TPC}

TPC of crude-WEP was over twice that of purified-WEP analyzed by FC method $(6.18 \pm 0.84$ vs $2.96 \pm 0.10 \mathrm{mg}$ FAE/g) (Table 2) reflecting its higher antioxidant activity. The purification process probably removed considerable amount of phenolic compounds such as phenolic acids, flavonoids, phenolic acid diacyl glycerols, phenolic aldehydes and ferulates (Fardet, 2010). The most ample phenolic acid is FA followed by di-FA, sinapic acid, p-coumaric acid, caffeic acid and benzoic acid derivatives (Adom \& Liu, 2002). About $95 \%$ of phenolic compounds in cereal grains are linked to cell wall polysaccharides by ester bonds and classified as dietary fiber-phenolic compounds (Hatfield, Ralph, \& Grabber, 1999). Consequently, the addition of WB in yogurt might affect the gastrointestinal tract by acting like potential prebiotics, improving probiotic viability and functioning as antioxidants, especially after colonic fermentation (Fardet, 2010).

\subsection{TDF and its Phenolics}

\subsubsection{TDF}

TDF content $(53 \%)$ was counted as a sum of SDF (6\%) and IDF (47\%). The content and proportion of both DF fractions are diverse among different types of cereals. This might be due to differences in seed morphology among most cereal grains (including wheat, maize and barley). Most of them have higher IDF than SDF, with WB dietary fiber around $44.5 \%$ (Fardet, 2010). Also, the DF content of WB (containing both outer layers and germ) and WB (only outer layers) were found $52.2 \%$ and 59.3\%, respectively (Frolich \& Asp, 1981). Our results are in close range with the above studies and literature (Stevenson, Phillips, O'Sullivan, \& Walton, 2012).

\subsubsection{Phenolic Compounds from WB, SDF and IDF}

Table 3 shows the bound phenolic acid and flavonoid contents (mg/g of sample) of WB, IDF, and SDF. All three samples (WB, SDF, and IDF) were hydrolyzed prior to liquid-liquid extraction of bound phenolic acids. WB phenolic acid content $(2.64 \mathrm{mg} / \mathrm{g}$ ) was higher compared to that of total dietary fiber (IDF+SDF; $1.46 \mathrm{mg} / \mathrm{g}$ ). This was an expected result since each step of fractional DF extraction resulted in some phenolic acid loss (Guo \& Beta, 2013). IDF had higher total phenolic acid content compared to SDF fraction.

Table 3. HPLC profiles of bound-phenolic compounds in the fractions of both soluble/insoluble dietary fibers and WB

\begin{tabular}{lccc}
\hline Phenolics & SDF $^{*}$ & IDF & WB \\
\hline Gallic & $0.10^{\mathrm{a}}$ & $0.15^{\mathrm{b}}$ & $0.24^{\mathrm{c}}$ \\
Proto-catechuic & $\mathrm{nd}$ & $0.06^{\mathrm{cb}}$ & $\mathrm{nd}$ \\
p-OH-benzoic & $0.03^{\mathrm{c}}$ & $0.08^{\mathrm{cb}}$ & $0.17^{\mathrm{d}}$ \\
Chlorogenic & $\mathrm{nd}$ & $\mathrm{nd}$ & $0.89^{\mathrm{b}}$ \\
Vanillic & $0.01^{\mathrm{cd}}$ & $\mathrm{nd}$ & $0.04^{\mathrm{e}}$ \\
Syringic & $0.01^{\mathrm{cd}}$ & $0.03^{\mathrm{d}}$ & $0.05^{\mathrm{e}}$ \\
p-coumaric & $0.02^{\mathrm{cd}}$ & $0.07^{\mathrm{cb}}$ & $\mathrm{nd}$ \\
Sinapic & $\mathrm{nd}$ & $\mathrm{nd}$ & $0.11^{\mathrm{de}}$ \\
Ferulic & $0.06^{\mathrm{b}}$ & $0.84^{\mathrm{a}}$ & $1.13^{\mathrm{a}}$ \\
\hline Total phenolic acids (PA) & $\mathbf{0 . 2 3} \pm \mathbf{0 . 0 2}$ & $\mathbf{1 . 2 3} \pm \mathbf{0 . 0 1}$ & $\mathbf{2 . 6 4} \pm \mathbf{0 . 2 5}$ \\
\hline Catechin & $0.01^{\mathrm{cd}}$ & $0.07^{\mathrm{cb}}$ & $0.10^{\mathrm{de}}$ \\
Rutin & $0.03^{\mathrm{c}}$ & $0.07^{\mathrm{cb}}$ & $0.13^{\mathrm{de}}$ \\
Quercetin-3-beta glucoside & $0.03^{\mathrm{c}}$ & $0.08^{\mathrm{cb}}$ & $\mathrm{nd}$ \\
Epicatechin gallate & $\mathrm{nd}$ & $\mathrm{nd}$ & $0.12^{\mathrm{de}}$ \\
\hline Total Flavonoid (FC) & $\mathbf{0 . 0 7} \pm \mathbf{0 . 0 1}$ & $\mathbf{0 . 2 2} \pm \mathbf{0 . 0 9}$ & $\mathbf{0 . 3 5} \pm \mathbf{0 . 1 2}$ \\
\hline Total phenolics (PA+FC) & $\mathbf{0 . 3 0} \pm \mathbf{0 . 0 2}$ & $\mathbf{1 . 4 5} \pm \mathbf{0 . 0 5}$ & $\mathbf{2 . 9 9} \pm \mathbf{0 . 1 7}$ \\
\hline
\end{tabular}

\footnotetext{
*Values are means of triplicates, and different letters in columns are significantly different $(P<0.05)$ in Duncan's multiple range tests. $\mathrm{SDF}=$ Soluble dietary fiber fraction, $\mathrm{IDF}=$ Insoluble dietary fiber fractions, $\mathrm{WB}$ $=$ wheat bran, $n d=$ not detected.
}

Most total content of phenolic compounds (PA + FC) in both IDF and SDF fractions were found in insoluble fractions as in our previous study (Gunenc, et al., 2015). For example, $84.24 \%$ PA, 75.86\% FC and $82.86 \%$ of total phenolic compounds were found in IDF fractions. 
Nine phenolic acids including gallic, protocatechuic, p-OH-benzoic, chlorogenic, vanillic, syringic, p-coumaric, sinapic and ferulic acids were determined in HPLC analyses of WB, IDF, and SDF. Ferulic acid was the predominant phenolic acid, and mainly found as bound form in IDF (93.3\%). Also, gallic acid was predominant in SDF. Our findings are in parallel with the study of Guo and Beta (2013).

With HPLC, Four flavonoid peaks were identified and respectively assigned as catechin, rutin, quercetin-3-beta glucoside, and epicatechin gallate (Table 3). IDF had more flavonoids $(0.22 \mathrm{mg} / \mathrm{g})$ than SDF $(0.07 \mathrm{mg} / \mathrm{g})$. Those biologically active components have not received much consideration as the phytochemicals in fruits and vegetables although the increased consumption of whole grain products has been linked to a diminished risk of chronic diseases (Liu, 2007). Our flavonoid content findings were in the same range reported by Singh, Sharma and Sarkar (2012) and close range with the study of Feng and McDonald (1989) in which the mean flavonoid content of four wheat classes were characterized and reported to be $0.29 \mathrm{mg} / \mathrm{g}$, and our corresponding flavonoid content of total DF and WB were 0.29 and $0.35 \mathrm{mg} / \mathrm{g}$ respectively (Feng \& Mc Donald, 1989; Singh, Sharma, \& Sarkar, 2012).

\section{Conclusions}

This study showed that WB enhanced bacterial survival and growth in yogurt over 28 days cold storage period at $4^{\circ} \mathrm{C}$. The overall increase in TTA\% values in yogurts containing WB during the storage period suggest that WB could be consumed by probiotics. Furthermore, crude-WEP showed stronger antioxidants activity than purified-WEP as well as IDF has higher phenolic content compared to SDF. Consequently, DF can act as a carrier of phenolic compounds. It can be concluded that WB might be used as a potential source of prebiotics with higher antioxidant activity for functional foods and nutraceutical applications. Further investigations are needed for nutritive values (mineral solubility) and sensory evaluation of yogurt samples with WB addition.

\section{Acknowledgments}

This study was supported by the Ontario Ministry of Agriculture, Food and Rural Affairs (OMAFRA).

\section{References}

Aaby, K., Skrede, G., \& Wrolstad, R. E. (2005). Phenolic composition and antioxidant activities in flesh and achenes of strawberries (fragaria ananassa). Journal of Agricultural and Food Chemistry, 53, 4032-4040. http://dx.doi.org/10.1021/jf048001o

Adom, K. K., \& Liu, R. H. (2002). Antioxidant activity of grains. Journal of Agricultural and Food Chemistry, 50(21), 6182-6187. http://dx.doi.org/10.1021/jf0205099

Agil, R., \& Hosseinian, F. (2012). Dual Functionality of Triticle as a Novel Dietary Source of Prebiotics with Antioxidant Activity in Fermented Dairy Products. Plant Foods for Human Nutrition, 67, 88-93. http://dx.doi.org/10.1007/s11130-012-0276-2

Behrad, S., Yusof, M. Y., Goh, K. L., \& Baba, A. S. (2009). Manipulation of probiotics fermentation of yogurt by cinnamon and licorice: Effects on yogurt formation and inhibition of helicobacter pylori growth in vitro. World Academy of Science, Engineering and Technology, 60, 590-594. http://dx.doi.org/10.1.1.193.4755

Beshkova, D. M., Simova, E. D., Frengova, G. I., Simov, Z. I., \& Dimitrov, Z. P. (2003). Production of volatile aroma compounds by kefir starter cultures. International Dairy Journal, 13, 529-535. http://dx.doi.org/10.1016/S0958-6946(03)00058-X

Bomba, A., Nemcová, R., Mudronová, D., \& Guba, P. (2002). The possibilities of potentiating the efficacy of probiotics. Trends in Food Science and Technology, 13, 121-126. http://dx.doi.org/10.1016/S0924-2244(02)00129-2

Chakraborti, C. K. (2011). The status of synbiotics in colorectal cancer. Life Sciences and Medicine Research, 20, $1-15$.

Costa, G. E. A., Queiroz-Monici, K. S., Machado-Reis, S. M. P., \& Oliveira, A. C. (2006). Chemical composition, dietary fiber and resistant starch contents of raw and cooked pea, common bean, chickpea and lentil legumes. Food Chemistry, 94, 327-330. http://dx.doi.org/10.1016/j.foodchem.2004.11.020

Daniells, S. (2010). Prebiotic wheat bran extract gets FDA GRAS no objection. Nutraingredients-USA.com. Retrieved from http://www.nutraingredients-usa.com/Suppliers2/Prebiotic-wheat-bran-extract-gets-FDA-GRAS-no-objecti on." 
Escarnot, E., Aguedo, M., Agneessens, R., Wathelet, B., \& Paquot, M. (2011). Extraction and characterization of water-extractable and water-unextractable arabinoxylans from spelt bran: Study of the hydrolysis conditions for monosaccharides analysis. Journal of Cereal Science, 53(1), 45-52. http://dx.doi.org/10.1016/j.jcs.2010.09.002

Fardet, A. (2010). New hypotheses for the health-protective mechanisms of whole-grain cereals: what is beyond fiber? Nutrition research reviews, 23(1), 65-134. http://dx.doi.org/ 10.1017/S0954422410000041

Feng, Y., \& Mc Donald, C. E. (1989). Comparison of flavonoids in bran of four classes of wheat. Cereal Chemistry, 66(6), 516-518. http://dx.doi.org/10.1007/s13197-011-0276-5

Francois, I. E. J. A., Lescroart, O., Veraverbeke, W. S., Marzorati, M., Possemiers, S., et al. (2012). Effects of a wheat bran extract containing arabinoxylan oligosaccharides on gastrointestinal health parameters in healthy adult human volunteers: a double-blind, randomised, placebo-controlled, cross-over trial. British Journal of Nutrition, 108(12), 2229-2242 2214 p. http://dx.doi.org/10.1017/S0007114512000372

Frolich, A., \& Asp, N. G. (1981). Dietary fiber content in cereals in Norway. Cereal Chemistry, 58(6), 524-527. http://dx.doi.org/10.1371/journal.pone.0039361

Gao, L., Wang, S., Oomah, B. D., \& Mazza, G. (2002). Wheat quality elucidation. In P. Ng, Wrigley, C.W. (Ed.), Wheat Quality: Antioxidant Activity of Wheat Millstreams (pp. 219-233). St.Paul, MN: American Association of Cereal Chemists International.

Gunenc, A., HadiNezhad, M., Farah, I., Hashem, A., \& Hosseinian, F. (2015). Impact of supercritical $\mathrm{CO}_{2}$ and traditional solvent extraction systems on the extractability of alkylresorcinols, phenolic profile and their antioxidant activity in wheat bran. J. Funct. Foods, 12, 109-119. http://dx.doi.org/10.1016/j.jff.2014.10.024

Gunenc, A., HadiNezhad, M., Tamburic-Illincic, L., Mayer, P. M., \& Hosseinian, F. (2013). Effects of region and cultivar on alkylresorcinols content and composition in wheat bran and their antioxidant activity. Journal of Cereal Science, 57, 405-410. http://dx.doi.org/10.1016/j.jcs.2013.01.003

Gunenc, A., Tavakoli, H., Seetharaman, K., Mayer, P. M., Fairbanks, D., et al. (2013). Stability and antioxidant activity of alkylresorcinols in breads enriched with hard and soft wheat brans. Food Research International, 51(2), 571-578. http://dx.doi.org/10.1016/j.foodres.2013.01.033

Guo, W., \& Beta, T. (2013). Phenolic acid composition and antioxidant potential of insoluble and soluble dietary fiberextracts derived from select whole-grain cereals. Food Research International, 51, 518-525. http://dx.doi.org/10.1016/j.foodres.2013.01.008

Hatfield, R. D., Ralph, J., \& Grabber, J. H. (1999). Cell wall cross-linking by ferulates and diferulates in grasses. Journal of the Science of Food and Agriculture, 79, 403-407. http://dx.doi.org/ 10.1002/(SICI)1097-0010(19990301)79:3<403::AID-JSFA263>3.0.CO;2-0

Hosseinian, F. S., \& Mazza, G. (2009). Triticale bran and straw: Potential new sources of phenolic acids, proanthocyanidins, and lignans. Functional Foods, 1, 57-64. http://dx.doi.org/10.1007/s11130-012-0276-2

Hromádková, Z., Paulsen, B. S., Polovka, M., Košt’́lová, Z., \& Ebringerová, A. (2013). Structural features of two heteroxylan polysaccharide fractions from wheat bran with anti-complementary and antioxidant activities. Carbohydrate Polymers, 93(1), 22-30. http://dx.doi.org/ 10.1016/j.carbpol.2012.05.021

Jonnalagadda, S. S., Harnack, L., Liu, R. H., McKeown, N., Seal, C., et al. (2011). Putting the whole grain puzzle together: Health benefits associated with whole grains-Summary of American Society for Nutrition 2010 Satellite Symposium. American Society for Nutrition, 141(5), 10115-10225. http://dx.doi.org/10.3945/jn.110.132944

Kanmani, P., Satish Kumar, R., Yuvaraj, N., Paari, K. A., Pattukumar, V., et al. (2013). Probiotics and its functionally valuable products-A Review. Critical Reviews in Food Science and Nutrition, 53(6), 641-658. http://dx.doi.org/10.1080/10408398.2011.553752

Kim, K.-H., Tsao, R., Yang, R., \& Cui, S. W. (2006). Phenolic acid profiles and antioxidant activities of wheat bran extracts and the effects of hydrolysis conditions. Food Chemistry, 95, 466-473. http://dx.doi.org/10.1016/j.foodchem.2005.01.032

Li, W., Hosseinian, F. S., Tsopmo, A., Friel, J. K., \& Beta, T. (2009). Evaluation of antioxidant capacity and aroma quality of breast milk. Nutrition, 25(1), 105-114. http://dx.doi.org/10.1016/j.nut.2008.07.017

Liu, R. H. (2007). Whole grain phytochemicals and health. Journal of Cereal Science, 46, 207-219. http://dx.doi.org/10.1002/9780470277607.ch15 
Mellen, P. B., Walsh, T. F., \& Herrington, D. M. (2008). Whole grain intake and cardiovascular disease: A meta-analysis. Nutrition, Metabolism and Cardiovascular Diseases, 18, 283-290. doi: 10.1136/bmj.i2716

Moore, J., Liu, J.-G., Zhou, K., \& Yu, L. L. (2006). Effects of genotype and environment on the antioxidant properties of hard winter wheat bran. Journal of Agricultural and Food Chemistry, 54(15), 5313-5322. http://dx.doi.org/10.1021/jf0603811

Murtaugh, M. A., Jacobs, D. R., Jacob, B., Steffen, L. M., \& Marquart, L. (2003). Epidemiological support for the protection of whole grains against diabetes. Proceedings of the Nutrition Society, 62, 143-149. http://dx.doi.org/10.1079/PNS2002223

Okarter, N., Liu, C.-S., Sorrells, M. E., \& Liu, R. H. (2010). Phytochemical content and antioxidant of six diverse varieties of whole wheat. Food Chemistry, 119, 249-257. http://dx.doi.org/10.1016/j.foodchem.2009.06.021

Ou, B., Huang, D., Hampsch-Woodill, M., Flanagan, J. A., \& Deemer, E. K. (2002). Analysis of antioxidant activities of common vegetables employing oxygen radical absorbance capacity (ORAC) and ferric reducing antioxidant power (FRAP) assays:a comparative study. Journal of Agricultural and Food Chemistry, 50, 3122-3128. http://dx.doi.org/10.1021/jf0116606

Rao, R. S. P., \& Muralikrishna, G. (2006). Water soluble feruloyl arabinoxylans from rice and ragi; changes upon malting and their consequence on antioxidant activity. Phytochemistry, 67, 91-99. http://dx.doi.org/10.1016/j.phytochem.2005.09.036

Rattanachaikunsopon, P., \& Phumkhachorn, P. (2010). Lactic acid bacteria: Their antimicrobial compounds and their uses in food production. Annals of Biological Research, 1, 218-228. http://dx.doi.org/10.1007/s12393-012-9051-2

Santo, A. P., Silva, R. C., Soares, F., Anjos, D., Gioielli, L. A., et al. (2010). Acai pulp addition improves fatty acid profile and probiotic viability in yogurt. International Dairy Journal, 20, 415-422. http://dx.doi.org/10.1016/j.idairyj.2010.01.002

Schatzkin, A., Park, Y., Leitzmann, M. F., Hollenbeck, A. R., \& Cross, A. J. (2008). Prospective study of dietary fiber, whole grain foods, and small intestinal cancer. Gastroenterology, 135, 1163-1167. http://dx.doi.org/10.1053/j.gastro.2008.07.015

Sengun, I. Y., Nielsen, D. S., Karapinar, M., \& Jakobsen, M. (2009). Identification of lactic acid bacteria isolated from tarhana, a traditional Turkish fermented foods. International Journal of Microbiology, 135, 105-111. http://dx.doi.org/10.1016/j.ijfoodmicro.2009.07.033

Singh, B., Sharma, H. K., \& Sarkar, B. C. (2012). Optimization of extraction of antioxidants from wheat bran (Triticum spp.) using response surface methodology. Journal of Food Science and Technology, 49(3), 294-308. http://dx.doi.org/10.1007/s13197-011-0276-5

Stevenson, L., Phillips, F., O'Sullivan, K., \& Walton, J. (2012). Wheat bran: its composition and benefits to health, a European perspective. International Journal of Food Sciences and Nutrition, 63(8), 1001-1013. http://dx.doi.org/10.3109/09637486.2012.687366

Topping, D. (2007). Cereal complex carbohydrates and their contribution to human health. Journal of Cereal Science, 46(3), 220-229. http://dx.doi.org/10.1016/j.jcs.2007.06.004

Vasiljevic, T., \& Shah, N. P. (2008). Probiotics-from metchnikoff to bioactives. International Dairy Journal, 18, 714-728. http://dx.doi.org/10.1016/j.idairyj.2008.03.004

Veenashri, B. R., \& Muralikrishna, G. (2011). In vitro anti-oxidant activity of xylo-oligosaccharides derived from cereal and millet brans - A comparative study. Food Chemistry, 126(3), 1475-1481. http://dx.doi.org/10.1007/s13197-010-0226-7

\section{Copyrights}

Copyright for this article is retained by the author(s), with first publication rights granted to the journal.

This is an open-access article distributed under the terms and conditions of the Creative Commons Attribution license (http://creativecommons.org/licenses/by/4.0/). 